\title{
INFLUENCE OF GENETIC POTENTIAL ON THE LEVEL OF DAIRY PRODUCTIVITY OF COWS
}

\author{
LYUDMILA V. HOLODOVA
}

Mari State University, Yoshkar, Ola City, Russia

\begin{abstract}
Research on the influence of the genetic potential of cows on the level of their milk productivity was carried out on the basis of the Prigorodny Agricultural production cooperative - the Republic of Mari El of the Russian Federation. The object of research was Holstein cows of black-and-white breed in the number of 352 cows.The level of dairy productivity of cows in the Prigorodny Agricultural production cooperative is at a high level. The milk yield of cows in the average herd made up $5805 \mathrm{~kg}$ Mass fraction of fat of $4.01 \%$. The mass fraction of protein is $3.03 \%$. When studying the influence of the genetic potential of cows on the level of dairy productivity in the farm, it was found that with an increase in the genetic potential, the milk yield of cows increases. A small positive correlation was found between the parent index of cows and milk yields (for 1 lactation, maximum and average) $(r=0.2)$.As a result of research, it was found that the realization of the genetic potential in animals of different lines varied: milk yield-from $85 \%$ to 110\%, fat mass fraction - from 97 to 102\%, protein-from 95 to $96 \%$. It was found that animals of the Pubst Governer 882933 line realized their genetic potential.

KEYWORDS: Cattle, Dairy Productivity, Genetic Potential, Ancestors, Lines
\end{abstract}

Received: Jun 08, 2020; Accepted: Jun 28, 2020; Published: Sep 08, 2020; Paper Id.: IJMPERDJUN20201103

\section{INTRODUCTION}

Over the past 50 years, milk production from dairy cows has increased significantly worldwide [3]. Our country has a variety of dairy breeds with a genetic potential of 5000-9000 kg of milk. The preservation and improvement of this valuable gene pool is carried out in breeding farms, which include the Prigorodny Agricultural production cooperative of the Russian Federation.

The specificity of dairy cattle breeding determines the features of intensification, due to which the efficiency of the industry depends on the degree of use of the genetic capabilities of animals [6,7,8].Dairy breeds require scientists to have in-depth knowledge on the formation of milk productivity [2]. According to data received from: T. Johnson, K. Eketone, L. McNaughton, K. Tipladyand C. Couldrey [5]- the genetic potential of animals allows you to increase the productivity of dairy cows more than twice.According to some authors [1,4,9], the widespread breeding use of highly productive cows contributes to the accumulation of valuable genetic potential in subsequent generations, which increases the chances of obtaining more productive breeding herds.

\section{MATERIALS AND METHODS}

The research was conducted on the basis of the Prigorodny Agricultural production cooperative of the Republic of Mari El of the Russian Federation.The object of research was Holstein cows of black-and-white breed in the number of 352 cows. 
The aim of the research is to identify the influence of the genetic potential of cows on their level of milk productivity. To achieve this goal it was necessary to solve the following tasks:

- $\quad$ study the dairy productivity of the herd;

- $\quad$ determine the potential of animals of different genotypes;

- $\quad$ analyze the implementation of the genetic potential of cows.

To determine the potential productivity of animals, the parental index of a cow (PIC) was calculated using the formula: $\mathrm{PIC}=(2 \mathrm{M}+\mathrm{MO}+\mathrm{MM}) / 4$,

Where, $\mathrm{M}$ - average productivity for the mother;

MM-average productivity for the mother of the mother;

MO - average productivity for the father's mother.

Realization of genetic potential (RGP) for cows was calculated using the formula: $\quad R G P=\frac{F}{0} \times 100 \%$

Where, F - actual milk yield of cow;

O-parent index of the cow.

\section{RESULTS AND DISCUSSIONS}

Studies have shown that the level of dairy productivity of cows In the agricultural production cooperative Prigorodny is at a high level. The milk yield of cows in the average herd made up $5805 \mathrm{~kg}$ Mass fraction of fat of $4.01 \%$. The mass fraction of protein is $3.03 \%$.

As a result of research, it was found that the milk yield of cows increases with the age of animals and reaches a maximum of $6011 \mathrm{~kg}$ by the third lactation. After that, there is a decline in productivity to $5334 \mathrm{~kg}$ for the period of 9 lactation.

The main method of breeding used in breeding farms is line breeding. When breeding in a herd of selected representatives of highly productive lines, the number of animals with valuable genetic qualities increases and the breed improves. Analyzing the level of milk productivity of cows of different linear affiliation for 1 lactation, it was found: firstborn cows of the line R. Sovering 198998 exceeded cows of the line V. B. Ideal 1013415 - by $198 \mathrm{~kg}$; M. Chieftain 95697

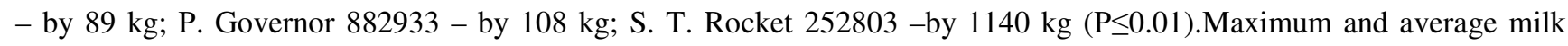
yields are highest in cows of the P. Governor 882933 line. In terms of milk yield for the highest lactation, cows of this line were fed more than those of the line V. B. Ideal 1013415 - by $675 \mathrm{~kg}(\mathrm{P} \leq 0.01)$; M. Chieftain 95697 - by $537 \mathrm{~kg}$; R. Sovering 198998 - by $521 \mathrm{~kg}(\mathrm{P} \leq 0.05)$; S. T. Rocket 252803-by $984 \mathrm{~kg}(\mathrm{P} \leq 0.01)$. On average, for a number of lactations: $406 \mathrm{~kg}(\mathrm{P} \leq 0.001), 57 \mathrm{~kg}, 133 \mathrm{~kg}, 752 \mathrm{~kg}(\mathrm{P} \leq 0.01)$. The fat content of milk was higher in cows of the M. Chieftain 95697 line, and averaged $3.95 \%$. The protein content of cows, depending on the linear affiliation, varied in the range of 3.01$3.03 \%$.

The analysis of potential possibilities of animals showed that the number of cows in the farm has a high genetic potential. The parent index for cows in the average herd for the yield of milk amounted to $6738 \mathrm{~kg}$ mass fraction of fat of 
$3.90 \%$. For the mass fraction of protein at 3.16\%. Animals of the S. T. Rocket 252803 line has the highest genetic potential. The parent index for milk yield in this group of cows was $7251 \mathrm{~kg}$. According to the mass fraction of fat-4.04\%. Studying the genetic potential of cows depending on the genotype of the father, it was found that the daughters of bulls Monument 1105 and Emirate 400134 have the highest genetic potential for milk yield - $7298 \mathrm{~kg}$ and $7273 \mathrm{~kg}$. Argon 1108 - for the mass fraction of protein in milk - 3.19\%. The descendants of Monument 1105 had the highest parental index for the mass fraction of fat $-3.97 \%$.

When studying the influence of the genetic potential of cows on the level of dairy productivity in the farm, it was found that with an increase in the genetic potential, the milk yield of cow's increases. A small positive correlation was found between the parent index for cows and milk yields (for 1 lactation, maximum and average) ( $\mathrm{r}=0.2$ ). As a result of the research, it was found that the maximum milk yield of $5889 \mathrm{~kg}$ was registered in first-born Chicks with a parent index of more than $9000 \mathrm{~kg}$. The Animals in this group exceeded their peers with a parent index of up to $5000 \mathrm{~kg}$ by $647 \mathrm{~kg}$, $5001-$ $6000 \mathrm{~kg}$ by $630 \mathrm{~kg}, 6001-7000 \mathrm{~kg}$ by $501 \mathrm{~kg}, 7001-8000 \mathrm{~kg}$ by $197 \mathrm{~kg}, 8001-9000 \mathrm{~kg}$ by $188 \mathrm{~kg}($ table 1$)$.

Table 1: Effect of Genetic Potential on Cow Milk Yield

\begin{tabular}{|c|c|c|c|c|c|c|c|c|c|c|}
\hline \multirow{3}{*}{$\begin{array}{c}\text { Parent Index for Cows by } \\
\text { Milk Yield, Kg }\end{array}$} & \multirow{3}{*}{$\mathbf{N}$} & \multicolumn{9}{|c|}{ Milk Yield, Kg } \\
\hline & & \multicolumn{3}{|c|}{ For 1 Lactation } & \multicolumn{3}{|c|}{$\begin{array}{l}\text { Thehighest } \\
\text { Lactation }\end{array}$} & \multicolumn{3}{|c|}{$\begin{array}{c}\text { The Average } \\
\text { Lactation }\end{array}$} \\
\hline & & $\mathbf{M}$ & M & $\mathrm{Cv}, \%$ & $\mathbf{M}$ & $\mathbf{M}$ & $\mathrm{Cv}, \%$ & M & $\mathbf{M}$ & $\mathrm{Cv}, \%$ \\
\hline upto 5000 & 25 & 5242 & 154,6 & 14,5 & 6212 & 128,2 & 10,3 & 5585 & 88,8 & 8,0 \\
\hline $5001-6000$ & 94 & 5259 & 88,7 & 16,3 & 6660 & 77,5 & 11,3 & 5765 & 49,2 & 8,3 \\
\hline $6001-7000$ & 108 & 5388 & 89,7 & 17,3 & 6600 & 70,8 & 11,1 & 5818 & 58,5 & 10,4 \\
\hline $7001-8000$ & 73 & 5692 & 135,5 & 20,3 & 6529 & 86,6 & 11,3 & 5883 & 81,4 & 11,8 \\
\hline $8001-9000$ & 37 & 5701 & 111,4 & 11,7 & 6442 & 145,5 & 13,7 & 5792 & 88,2 & 9,3 \\
\hline 9001 andmore & 15 & 5889 & 303,2 & 19,9 & 6770 & 180,0 & 10,3 & 5969 & 140,1 & 9,1 \\
\hline
\end{tabular}

The variability of milk yield in the study groups ranged from 11.7 to $20.3 \%$. At maximum milk yield, the highest indicator is higher by $558 \mathrm{~kg}(\mathrm{P} \leq 0.01)$. When studying the effect of the genetic potential of cows on milk yield at the highest lactation, the best results were shown by cows whose parent index was more than $9000 \mathrm{~kg}$. The milk yield of this group of cows was $6770 \mathrm{~kg}$. Similar results were obtained for the average milk yield for a number of lactations. Cows with a parent index of more than $9000 \mathrm{~kg}$ of milk had higher rates of milk yield for a number of lactations.

Variability of milk yield in the groups with the highest lactation in the range-10.3-13.7\%. Variability in groups by average milk yield is 8.0-11.8\%.Analysis of the effect of genetic potential on the mass fraction of fat in cow's milk shows that in the first lactation, in the highest and in the average lactation for a number of lactations, the lowest fat content of milk had cows with a parent index of $3.6 \%$ or less (table 2). The mass fraction of fat in milk in this group of cows for 1 lactation was $3.89 \%$. The mass fraction of fat in milk for the highest lactation is $3.93 \%$. The mass fraction of fat in milk on average is $3.85 \%$. The most fat-dairy cows with a parent index of more than $3.8 \%$. The fat content of the milk of such cows in 1 lactation was equal to $3.91-3.93 \%$. The fat content of the milk of such cows in the highest lactation is $4.02 \%$. The fat content of the milk of such cows is on average $3.9 \%$.

The variability of the mass fraction of fat in milk, depending on the value of the parent index for cows, fluctuated for 1 lactation $-2.9-5 \%$. In the highest lactation-1.1-2.2\%, on average-2.1-4\%. 
Table 2: Effect of Genetic Potential on the Mass Fraction of Cow Fat

\begin{tabular}{|c|c|c|c|c|c|c|c|c|c|c|}
\hline \multirow{3}{*}{$\begin{array}{c}\text { Parent Index } \\
\text { for Cows by } \\
\text { Mass Fraction } \\
\text { of Fat, \% }\end{array}$} & \multirow{3}{*}{$\mathbf{N}$} & \multicolumn{9}{|c|}{ Massfraction of Fat, \% } \\
\hline & & \multicolumn{3}{|c|}{ For 1 Lactation } & \multicolumn{3}{|c|}{ The Highest Lactation } & \multicolumn{3}{|c|}{ The Average Lactation } \\
\hline & & $\mathbf{M}$ & m & $\mathrm{Cv}, \%$ & $\mathbf{M}$ & $\mathbf{m}$ & $\mathrm{Cv}, \%$ & $\mathbf{M}$ & m & $\begin{array}{c}\mathrm{Cv}, \\
\%\end{array}$ \\
\hline 3,6 orless & 4 & 3,89 & 0,06 & 2,9 & 3,93 & 0,04 & 2,1 & 3,85 & 0,02 & 1,1 \\
\hline $3,61-3,8$ & 85 & 3,91 & 0,02 & 4,4 & 4,00 & 0,01 & 3,1 & 3,89 & 0,01 & 1,7 \\
\hline $3,81-4,00$ & 177 & 3,93 & 0,01 & 4,8 & 4,02 & 0,01 & 4,0 & 3,90 & 0,01 & 2,3 \\
\hline 4,01 ormore & 86 & 3,93 & 0,02 & 5,0 & 4,02 & 0,02 & 3,9 & 3,90 & 0,01 & 2,2 \\
\hline
\end{tabular}

Analysis of the effect of genetic potential on the mass fraction of protein during the first lactation shows the maximum value for cows with a genetic potential of $3.31 \%$ or more.

The mass fraction of protein in these cows in 1 lactation was 3.09\%. The mass fraction of protein for the highest lactation is $3.14 \%$. The mass fraction of protein on average for a number of lactations is $3.05 \%$. Animals with a parent index of 3.21-3.3\% took the second place in terms of protein content. The mass fraction of protein in the milk of these cows for 1 lactation was $3.03 \%$. The mass fraction of protein in the milk of these cows for the highest lactation is $3.09 \%$. The mass fraction of protein in the milk of these cows is on average $3.04 \%$ (table 3 ).

The coefficient of variation in the mass fraction of protein in animals, depending on the value of the parent index, ranged from 3.2 to $7 \%$ per 1 lactation. The coefficient of variation of the mass fraction of protein for maximum lactation is from 2 to $6.6 \%$. The coefficient of variation of the protein mass fraction on average for a number of lactations is from 0.5 to $4.6 \%$.

Table 3: Effect of Genetic Potential on the Mass Fraction of Cow Protein

\begin{tabular}{|c|c|c|c|c|c|c|c|c|c|c|}
\hline \multirow{3}{*}{$\begin{array}{l}\text { Parent Index } \\
\text { for Cows by } \\
\text { Mass Fraction } \\
\text { of Protein, \% }\end{array}$} & \multirow{3}{*}{$\mathbf{n}$} & \multicolumn{9}{|c|}{ Mass Fraction of Protein, \% } \\
\hline & & \multicolumn{3}{|c|}{ For 1 Lactation } & \multicolumn{3}{|c|}{ The Highest Lactation } & \multicolumn{3}{|c|}{ The Average Lactation } \\
\hline & & $\mathbf{M}$ & m & $\mathrm{Cv}, \%$ & $\mathbf{M}$ & $\mathbf{m}$ & $\mathrm{Cv}, \%$ & $\mathbf{M}$ & m & $\mathrm{Cv}, \%$ \\
\hline 3,00 orless & 14 & 3,01 & 0,025 & 3,2 & 3,08 & 0,027 & 3,3 & 3,03 & 0,004 & 0,5 \\
\hline $3,01-3,10$ & 100 & 3,01 & 0,014 & 4,6 & 3,08 & 0,012 & 3,7 & 3,03 & 0,014 & 4,6 \\
\hline $3,11-3,20$ & 151 & 3,01 & 0,007 & 2,9 & 3,08 & 0,005 & 2,0 & 3,03 & 0,002 & 0,7 \\
\hline $3,21-3,30$ & 48 & 3,03 & 0,020 & 5,2 & 3,09 & 0,010 & 2,7 & 3,04 & 0,010 & 1,5 \\
\hline 3,31 ormore & 39 & 3,09 & 0,030 & 7,0 & 3,14 & 0,030 & 6,6 & 3,05 & 0,010 & 1,8 \\
\hline
\end{tabular}

Studying the influence of the genetic potential of cows of different genotypes on the level of milk productivity, it was found that the daughters of bulls Stand 380 and Diver 1129 had the highest milk yields for maximum lactation - 7004 $\mathrm{kg}$ and $7071 \mathrm{~kg}$ (respectively) and had a high genetic potential - $6630 \mathrm{~kg}$ and $6191 \mathrm{~kg}$. It should be noted that the realization of the genetic potential for milk yield in these groups was $106 \%$ and $114 \%$. The daughter's genetic potential is high: Socrates 1035-112\%, Guidon 717-106\%, and Crown 87-103\%. Thedaughter'sgeneticpotentialislow: Emirate 400134-81\%, Lord $400114-84 \%$. The realization of the genetic potential for fat content of milk from cows of different origin ranged from 97 to $103 \%$. The realization of the genetic potential for protein content ranged from 95 to $97 \%$. The daughters of bulls realized their genetic potential better than others in terms of the mass fraction of fat:Stand 380, Crown 87, Diver 1129, Saddler 218, Socrates 1035, Argon 1108, V. Bandwagon 34365145.The daughters of bulls realized their genetic potential better than others in terms of the mass fraction of protein: Crown 87, Saddler 218, Diver 1129(figure 1). 


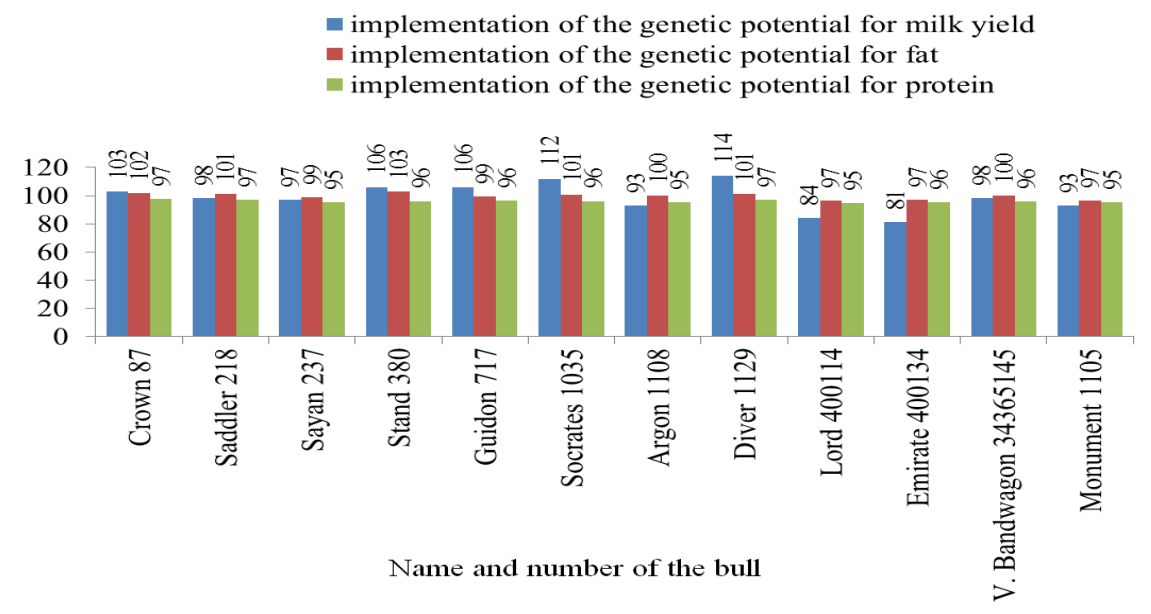

Figure 1: Realization of the Genetic Potential of Cows Depending on their Origin, \%.

The research objectives were to study the degree of realization of the genetic potential of cows depending on their linear affiliation.

A number of paratypical factors influence the realization of the genetic potential, the main of which are the feeding and maintenance conditions. It is necessary to determine its realization by black-and-white cows in the conditions of the Prigorodny Agricultural production cooperative.

As a result of the research, it was found that the realization of the genetic potential in animals of different lines in terms of milk yield ranged from $85 \%$ to $110 \%$ (figure 2). The genetic potential was realized by the animals of the Pubst Governor 882933 and Reflection Sovering 198998 lines-by 110\% and 102\% (respectively). Cows of the S. T. Rocket 252803 line failed to realize their genetic potential.The implementation of the genetic potential was only $85 \%$.

The realization of the genetic potential of the mass fraction of fat in cows, depending on the linear affiliation, ranged from 97\% (line S. T. Rocket 252803) to 102\% (line Pubst Governor 882933).

The realization of the ancestral potential for protein content in cows, depending on their lineage, ranged from 95-96\%.

As a result of research, it was found that the dairy productivity of cows, depending on the genetic potential, has differences. It was revealed that the parent index has an impact on quantitative and qualitative indicators of milk productivity.

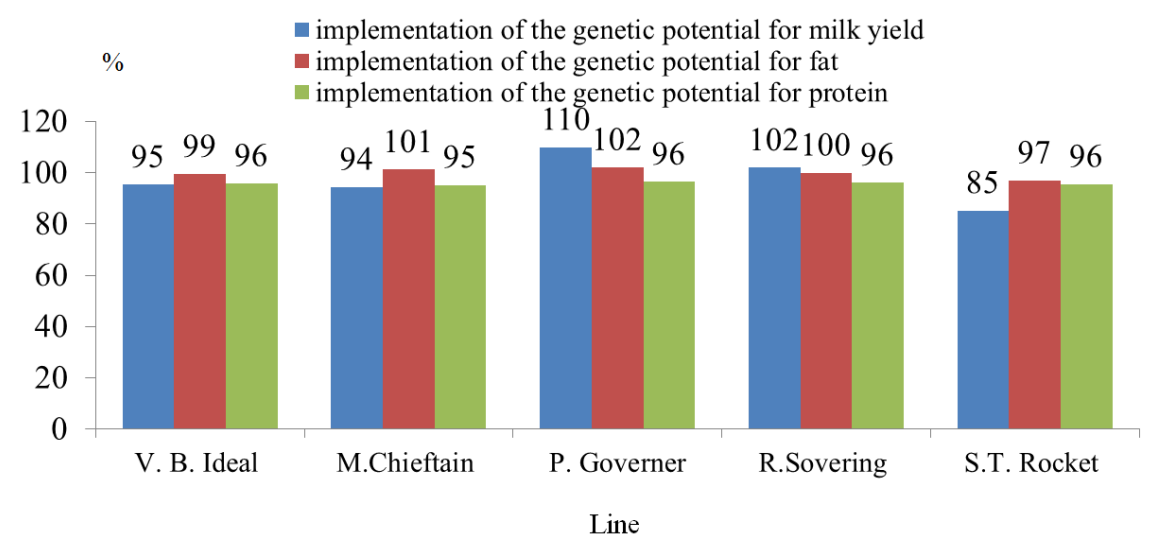

Figure 2: Implementation of the Genetic Potential of Animals of Different Lines. 


\section{CONCLUSIONS}

As a result of research, the influence of the genetic potential of cows on the level of milk productivity was established. It was found that the highest level of productivity was observed in cows whose parent index was more than $9000 \mathrm{~kg}$, in terms of fat mass fraction-more than $3.8 \%$, in terms of protein mass fraction-3.31\% or more. As a result of research, it was found that the realization of the genetic potential for milk yield in animals of different lines ranged from $85 \%$ to $110 \%$. Pubst Governor 882933 and Reflection Sovering 198998 realized their genetic potential by $110 \%$ and 102\% (respectively).The realization of the genetic potential of the mass fraction of fat in cows, depending on the linear affiliation, was at a high level - from 97\% (line S. T. Rocket 252803) to 102\% (line Pubst Governor 882933).

The realization of the ancestral potential for protein content in cows, depending on their lineage, ranged from 95$96 \%$.

The daughters of the bulls of Stand 380 and Diver 1129 had the highest yields for maximum lactation - $7004 \mathrm{~kg}$ and $7071 \mathrm{~kg}$ (respectively) and had a high genetic potential - $6630 \mathrm{~kg}$ and $6191 \mathrm{~kg}$. The realization of genetic potential in these groups was $106 \%$ and $114 \%$. High realization of the genetic potential of the daughter of Socrates $1035-112 \%$, Guidon $717-106 \%$ and Crown $87-103 \%$.

\section{REFERENCES}

1. Bebe B.O., J. Udo, H.M., Rowlands G.J. and Thorpe W. (2003): Smallholder dairy systems in the Kenya highlands: breed preferences and breeding practices. Livestock Production Sci., 82(2-3):117-127.

2. Cole J.B. and Null D.J. (2009): Genetic evaluation of lactation persistency for five breeds of dairy cattle. J. Dairy Sci., 92(5): 2248-2258.

3. Fulkerson W.J., Davison T.M., Garcia S.C., Hough G. and Blockey M. (2008): Holstein-Friesian Dairy Cows Under a Predominantly Grazing System: Interaction Between Genotype and Environment J. Dairy Sci., 91(2):826-839.

4. Hare E., Norman H.D. and Wright J.R. (2006): Survival Rates and Productive Herd Life of Dairy Cattle in the United States. J. Dairy Sci., 89( 9):3713-3720.

5. Johnson T., Eketone K., McNaughtonL.,Tiplady K. and CouldreyC. (2018):Mating strategies to maximize genetic merit in dairy cattle herds. J. Dairy Sci., 101(5):4650-4659.

6. Lopez-Villalobos N., Garrick D.J., Holmes, Blair C.W. and Spelman R.J. (2000): Effects of Selection and Crossbreeding Strategies on Industry Profit in the New Zealand Dairy Industry. J. Dairy Sci., 83(1):164-172.

7. Rincon E.J., Schermerhorn E.C., Mc Dowell R.E. and Mc Daniel B.T. (1982): Estimation of Genetic Effects on Milk Yield and Constituent Traits in Crossbred Dairy Cattle. J. Dairy Sci., 65(5): 848-856.

8. SewalemA.,Kistemaker G.J., Miglior F. and Van Doormaal B.J. (2006): Analysis of Inbreeding and Its Relationship with Functional Longevity in Canadian Dairy Cattle. J. Dairy Sci., 89(6): 2210-2216.

9. Spengler Neff A., Ivemeyer S. (2016): Differences between dairycows descending from artificial insemination bulls vs. dairy cows descending from natural service bulls on organic farms in Switzerland. J. LivestockSci., 185:30-33. 